\title{
BREXIT: THE END OR THE BEGINNING OF A LONG ROAD
}

\author{
Balázs H. VÁRADI - Tímea VÁRNAI - Barnabás VIRÁG
}

Globalisation and the loosening of credit conditions have led to an increase in income and wealth inequalities in the developed economies. The 2008-2009 crisis has forced a deleveraging process, leading to a prolonged recovery due to further demand cuts. The protracted economic problems and the inadequate management of economic policy in the EU increased social discontent that may have eventually contributed to Brexit. The short- and long-run impacts of the decision are difficult to judge, given that the details of the exit process cannot yet be known. Currently, there is a consensus among analysts that the negative economic effects could be greater in the UK in the short term. However, in the longer term, the UK may benefit from a potentially more flexible economic policy framework, while socio-political and economic risks are imposed on the European economy by the secondary effects due to its structural problems and the uncertain future of its institutional system.

As a small open economy, Hungary highly depends on the economic performance of its foreign trade partners. We have found that the economic impact of Brexit on Hungary remains moderate. Among the direct channels, the foreign trade channel may be the dominant. Meanwhile, the reduction of EU funds and remittances will affect the Hungarian growth only modestly. Hungary's vulnerability has improved substantially since the 2008-2009 crisis. Accordingly, potential secondround effects of Brexit may remain subdued and be mitigated through substantial room for manoeuvre for economic policies.

JEL classification indices: E02, E61, E62, G01, J31

Keywords: Brexit, European Union, policy co-ordination, financial crises, fiscal policy, wage inequalities

Barnabás Virág, corresponding author. Executive Director at the Magyar Nemzeti Bank. E-mail: viragb@mnb.hu

Balázs Váradi, Economist at the Magyar Nemzeti Bank. E-mail: varadib@mnb.hu

Tímea Várnai, Economist at the Magyar Nemzeti Bank. E-mail: varnait@mnb.hu 


\section{INTRODUCTION}

On June 23, 2016, when the majority of British voters decided to exit from the European Union, it became clear that the EU cannot and will not be what it used to be. The mapping of the underlying reasons and expected consequences of the decision, which was a surprise for many analysts, began immediately. More than three months elapsed, but still little is known about the details of the consequences. Presumably, negotiations are already being conducted behind the scenes, but the general public still does not know about the timing and the form of Britain's leaving the EU.

Regarding the reasons, however, a number of deeper analyses have been prepared. Some of them - especially in the beginning - considered the outcome as a hasty political decision and exaggerated emotional reaction of British society. In our opinion, this explanation captures the background of the events superficially and wrongly. Moreover, without exploring the background of the deeper reasons, this explanation may also be an obstacle to the necessary renewal of the economy and institutional system of Europe.

In economies, everything is interrelated. The economic, social, and political developments taking place in individual countries or regions cannot be separated from one another. The history of mankind has proven in innumerable instances that deepening economic problems sooner or later result in social tensions with serious political consequences. This is how it happens in our times as well.

Our study focuses on two issues. Firstly, we provide an overview of the economic reasons that may have contributed to the outcome of the UK referendum, and secondly, we examine the channels through which Brexit may affect the Hungarian economy.

\section{EUROPE IS FALLING BEHIND}

Some of the economic reasons date back several decades and are mainly related to the strengthening of globalisation tendencies. An extremely dynamic increase in global trade was observed in this period of hyperglobalisation, a term coined by Dani Rodrik. Turning into global production chains, large multinational companies relocated an increasing portion of the production of goods and services from more developed Western economies to Asian or Eastern European regions, where wage costs are lower. These decades coincide with the appearance of Asian economies - and within that of China in particular - in the global market and their extremely rapid development. In parallel with the increasing role of China, 
Table 1. Share of economic regions in the world GDP

\begin{tabular}{lrrrr} 
& 1995 & 2000 & 2005 & 2015 \\
\hline China & 2.4 & 3.6 & 4.8 & 14.8 \\
European Union & 31.1 & 26.5 & 30.4 & 22.1 \\
United States & 25.0 & 30.9 & 27.8 & 24.4 \\
Rest of the World & 41.5 & 39.1 & 37.0 & 38.7 \\
\hline World & 100.0 & 100.0 & 100.0 & 100.0
\end{tabular}

Note: Calculated from data in current prices.

Source: World Bank, WDI database.

the EU lost its economic weight in a steady and spectacular manner despite the enlargements (Table 1).

The relocation of production from more developed Western economies abroad resulted in uncertain income and labour market prospects in the sectors and regions concerned, and through that in rising social discontent. In the period preceding the 2008-2009 global financial crisis, its surfacing was prevented by the rapid increase in indebtedness. With easing of credit conditions and increase in loan outflows, even lower-income households were able to finance an expanding consumption path. The crisis and the ensuing inevitable adjustment put an end to this process.

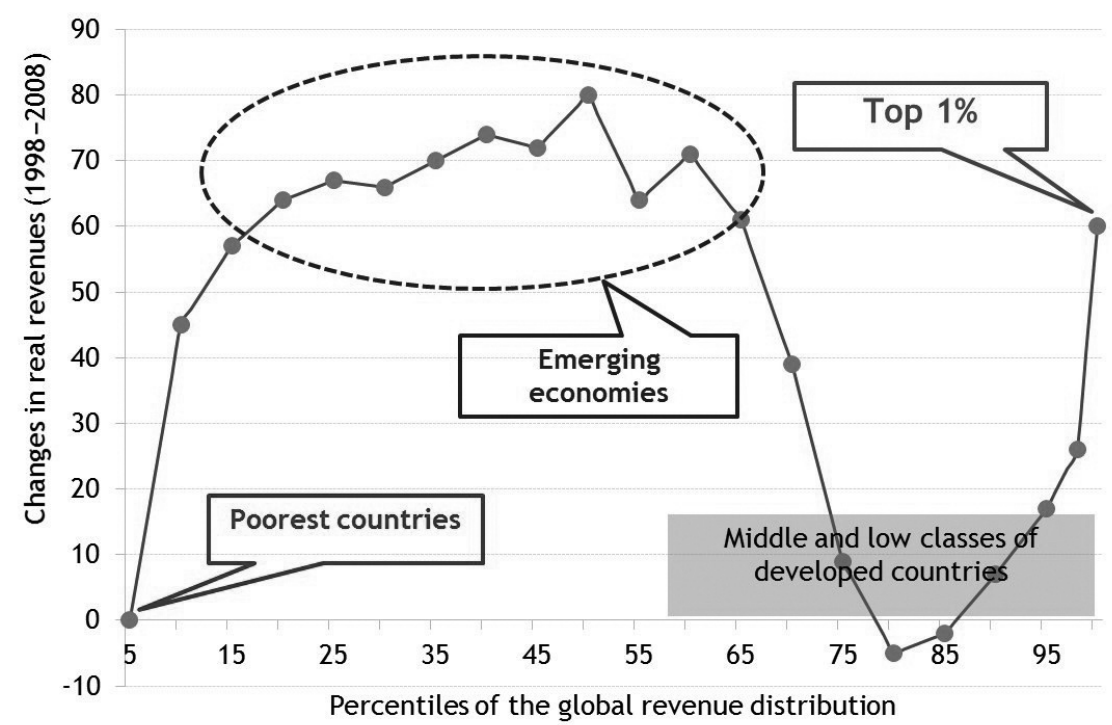

Figure 1. Change in real income at various percentiles of global income distribution Source: Milanovic (2012: 13). 
In the past decades, increase in disparities in income and wealth became a phenomenon that was in part closely related to globalisation. According to the findings of Branko Milanovic (2012), in global comparison, low growth or stagnation of real incomes mainly affected the low and middle classes of developed Western societies (Figure 1).

\section{EUROPEAN CRISIS MANAGEMENT AND ITS CONSEQUENCES}

The two afore-mentioned factors, which had been exerting their influence for decades, had a perceptible impact not only in Britain, but also in almost all of the more developed Western European countries. This was exacerbated by the consequences of the 2008-2009 global crisis and the subsequent protracted and extremely slow European recovery, which were particularly serious in some economies. These economic problems are mainly important in terms of the future of the euro area and the European Union, as the repercussions of Brexit are coming to the surface when, as a result of insufficient crisis management, increasingly larger social groups feel that they are the losers of globalisation and the financial crisis.

Already prior to the deepening of the crisis, the euro area and the European Union struggled with numerous problems: indebtedness was relatively high in the majority of member countries, competitiveness deteriorated in a number of countries, while significant internal imbalances evolved, and several countries faced problems with the banking sector as well.

During crisis management, the euro area put special emphasis on fiscal discipline, expecting it to stimulate economic growth. However, this dogma has been proved false by now. There is increasing evidence that in the case of a crisis featuring high imbalances, this type of economic policy only results in further problems; therefore, new, unconventional solutions are needed (more focus on burden sharing, speeding up portfolio cleaning in the banking sector, and targeted measures on incentivising credit growth). The global financial crisis that started in 2007 is different from the recessions experienced before. It is characterised by a much more protracted and deeper economic downturn than the crisis periods observed to date. Growth continues to be subdued, and unemployment is still considered high nearly one decade after the outbreak of the crisis. The number of unemployed in the EU still exceeds 22 million, while the youth unemployment rate is between $40-50 \%$ in the countries of Southern Europe. These unfavourable developments may be attributable basically to two underlying factors: firstly, the current crisis may be regarded as a kind of balance sheet crisis, which is characterised by slower recovery as a matter of course, and secondly, inadequate eco- 


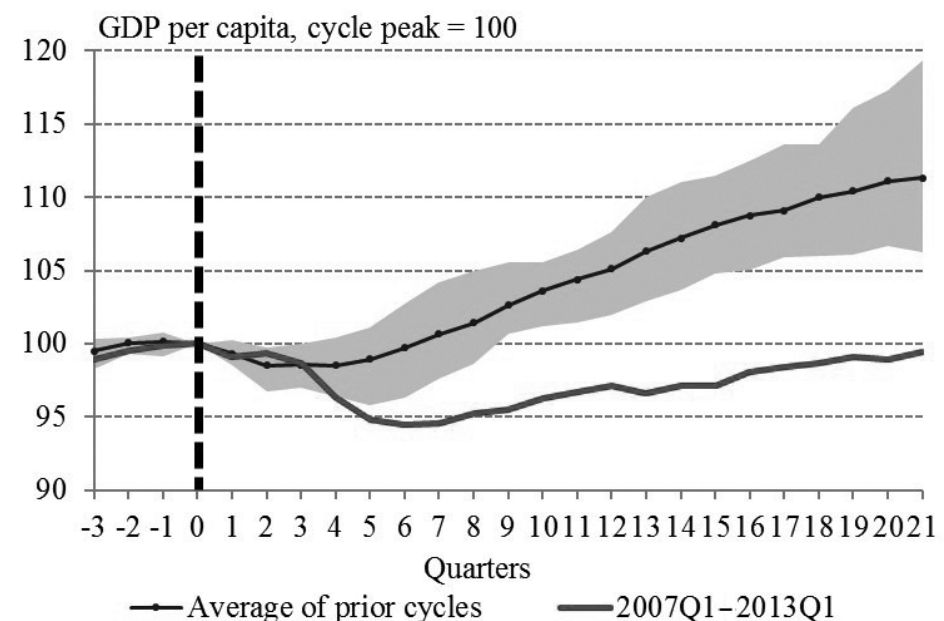

Figure 2. Output of the US economy during the previous recessions and present crisis Source: Atkinson et al. (2013: 4).

nomic policy responses to the crisis in some regions may also have contributed to the protraction of the crisis.

It is typical of a balance sheet crisis that following the bursting of the financial bubble evolving simultaneously with significant debt accumulation, economic agents restrain their spending and mainly focus on increasing their savings and repaying their debts. Reducing the outstanding debt can take place only by savings from incomes, although this is a protracted process (Koo 2008, 2014). As a result, balance sheet crises last longer and entail higher real economy costs than the usual recessions (Figure 2).

During the protracted balance sheet adjustment process, the efficiency of traditional monetary policy in stimulating the economy declines as a result of the unwillingness of economic agents to borrow, and thus the role of fiscal policy in the adequate support of economic growth may increase (Koo 2008).

Another feature of a balance sheet recession is that it can be characterised as a kind of stock type imbalance, whose treatment differs from that of flow imbalances. One of the deficiencies of European economic policy reactions to the crisis was that this feature of the balance sheet crisis was not taken into account. The overheating in the economy in the case of traditional business cycles is treated by the restraining of aggregate demand, which can be implemented by fiscal or monetary policy tightening (Csortos - Szalai 2015). However, the adequate treatment of a stock imbalance is different from that, as the reduction of the imbalance 
that built up during a longer period of time is also a protracted process, entailing a downturn in demand. In this case, stabilising the income position of economic agents and thus accelerating the balance sheet deleveraging process may ensure the earliest restoration of the balance and the pick-up in growth.

In Europe, however, in parallel with monetary policy stimulation, economic policy responses targeted the reduction of the budget deficit and increasing tightening measures. However, as a result of the significant macroeconomic uncertainty and the weak credit demand due to the deleveraging process, the efficiency of traditional monetary policy instruments declines. Moreover, during the current balance sheet crisis, when central banks' nominal interest rates declined close to the level considered as the lower bound, the coefficient of the fiscal multiplier is also greater (Christiano et al. 2011), and thus the real economy costs of the tightening measures also became higher. For the adequate management of the crisis, instead of the tightening measures, fiscal policy should have provided more leeway for facilitating the balance sheet adjustment of economic agents. It is only worth tightening the fiscal policy if the balance sheet deleveraging process has progressed sufficiently, and economic growth is already well founded.

Initially, both the United States and the EU reacted to the crisis by fiscal easing. Later, however, fiscal policies varied significantly across countries. Following the onset of economic upturn, the US continued to support the fiscal stimulus in order not to jeopardise the upturn with too early tightening (Csortos - Szalai 2015). However, at their meeting in Toronto in 2010, the G20 countries agreed on a gradual expenditure cut (G20 2010). Following that, fiscal policies were tightened and the adjustment of budgetary deficits was started both in the euro area and the United Kingdom. In the case of the euro area, it was justified by the fiscal rules as well as by the solvency problems of some periphery countries (Csortos - Szalai 2015). Nevertheless, the austerity measures resulted in economic downturn again in many euro area countries and in the United Kingdom, while the United States, realising the risks of restraining the stimulation, avoided the recurrence of the economic downswing (Figure 3). In the euro area, adequate crisis management was hindered by the institutional setup as well as the incompletion of the monetary and banking union. In addition, the recapitalisation of banks was also delayed, thus protracting bank deleveraging. Although the United Kingdom faced a milder economic downturn than the euro area, tightening policy in the euro area may have contributed to the result of the Brexit referendum.

Tightening policies not only entail significant welfare costs through the supply side channels, but they have an unfavourable impact on demand and thus on the labour market as well. Therefore, countries that have fiscal leeway should not concentrate on reducing their debt or on austerity measures (Ostry et al. 2016). 


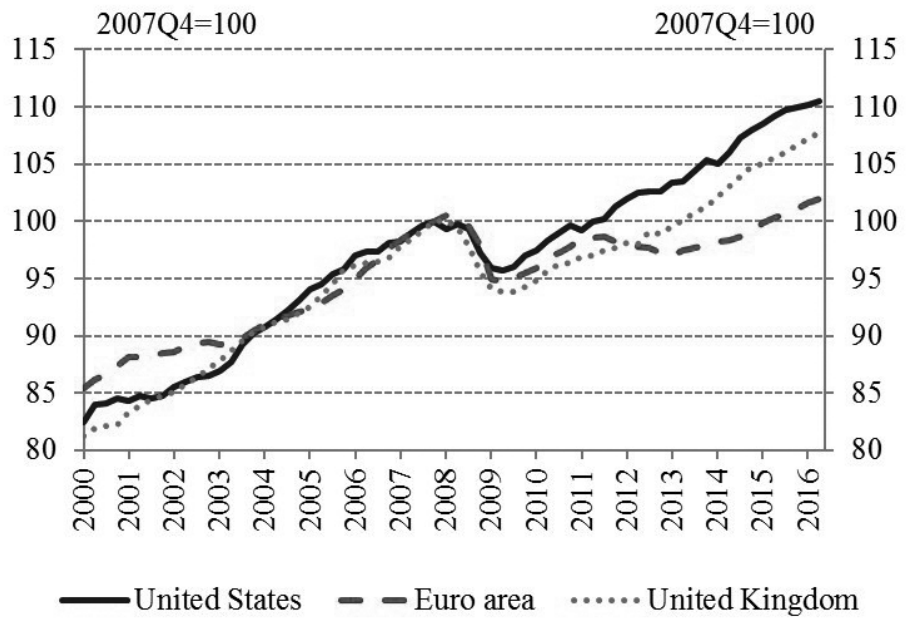

Figure 3. Developments in economic output in the USA, the euro area, and the UK

Source: OECD.

Another unfavourable side effect of a tight fiscal policy is that it adds to income disparities resulting in a lower growth path.

In the current crisis environment, labour market reforms - which improve the competitiveness of the economy under normal economic conditions - may also entail undesirable negative effects. In the past decades, great emphasis was placed on making the labour market more flexible in the United Kingdom. However, it often resulted in the dismissal of employees or the spread of part-time employment. For example, there was a significant increase in the number of zerohour employment contracts, which means that although the employer establishes permanent employment with the employee, the employer is not obliged to provide minimum working hours for the employee. All this significantly reduces the employees' social and economic safety. In the scholarly literature one can find opinions according to which the flexibility of labour market may also have unfavourable effect under certain conditions. In his study, Eggertsson calls attention to the fact that under certain conditions (zero nominal interest rate, deflationary pressure in the economy, and decline in output), aggregate employment may decline in spite of increasing labour supply (Eggertsson 2010). In addition, in an unfavourable demand environment, the greater flexibility of the labour market and wages may restrain economic output (Eggertsson - Krugman 2012; Eggertsson - Mehrotra 2014).

According to the latest consensus among leading economists about the reasons that triggered the euro area crisis, the growth and labour market prospects of 
the euro area continue to be extremely unfavourable and are expected to remain like that for years (Baldwin et al. 2015). Protracted economic problems, in turn, contribute to the strengthening of political groups that often hold extreme views, which may entail further unfavourable consequences. The authors underline that several European banks continue to struggle with problems due to the high portion of non-performing loans and other factors. Examining the reasons for the crisis, they call attention to the fact that basically it was not the high debts, but the high capital flows within the euro area and the resulting imbalances that caused the main problem, which was exacerbated by the fact that due to the single currency, individual economies were unable to become competitive through the depreciation of the exchange rate. In addition, institutional deficiencies of the euro area also made the situation worse.

Protracted, inadequately treated economic problems sooner or later entail social and political consequences as well. This is what has happened during the current crisis as well. Bell - Machin (2016) examined the correlation between the ratio of those who voted for leaving the European Union and their income position. According to their assumption, the income disparities observed in the United Kingdom may have considerably contributed to Brexit. Significantly higher portions of voters voted for the exit at the referendum on June 23, 2016, in the lowerincome regions. The arguments in Coyle's article are similar. In his opinion too, mainly the income disparities and the hopeless economic situations of those living in certain regions can be connected with the exit outcome of the referendum (Coyle 2016). In addition, the author considers the increasing income disparities across regions as one of the unfavourable consequences of globalisation.

\section{WHAT CAN GREAT BRITAIN AND EUROPE EXPECT?}

On the whole, until the closing of the exit negotiations and the obtaining of the details, an increase in the uncertainty surrounding economic decisions is expected. Especially in the case of Britain, it may result in the postponement and reconsideration of investment decisions. The resulting negative impacts on the real economy may be attenuated by improving export competitiveness stemming from a permanent depreciation of the exchange rate of the pound sterling. As far as external trade is concerned, both the EU and UK are expected to strive to maintain close relations.

Monetary policy conditions in both Britain and Europe may shift in the direction of maintaining permanently loose monetary conditions or further easing if necessary. The latest growth projections indicate a major deceleration for the 


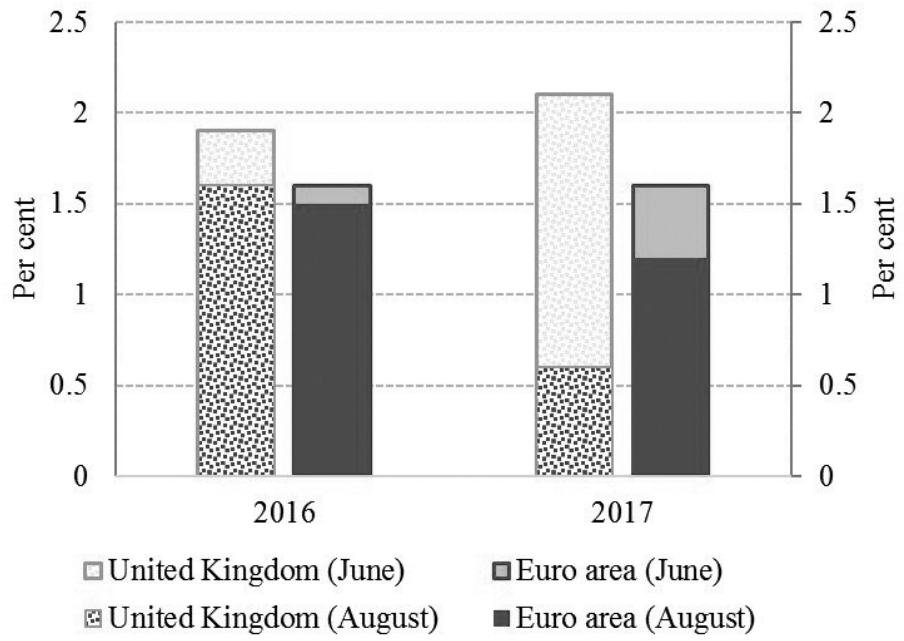

Figure 4. Growth forecasts before and after the Brexit referendum in the UK and in the euro area Source: Consensus Economics Forecasts on G7 and Western European Countries.

British economy, which may even mean that technical recession may evolve in some quarters (Figure 4).

In our opinion, however, the situation is not that clear. The structural problems characterizing the EU and, within that, of the euro area as well as the inflexibility of the institutional system substantially increased the system's exposure to confidence shocks. Accordingly, the longer-term impacts of Brexit as well as its social and political consequences affecting other countries will greatly depend on whether or not the institutional setup of the EU is able to efficiently manage the existing problems. If not, in the case of the EU it may lead to the evolving of negative social, political, and economic feedbacks as well as even longer-lasting negative real economy scenarios than currently expected.

\section{BREXIT AND THE HUNGARIAN ECONOMY}

The exit of Britain from the European Union is a socio-economic event of large volume, and its real economic impact assessment is a rather complex task. ${ }^{1}$ The reason is that the decision made in the referendum is of binary nature: in or out.

A number of attempts have been made to quantify the impact of Brexit e.g. Pain - Young (2004); Baker et al. (2016). 
In the course of changing the regime, the conditions of the exit and the extent of the change that will take place in the structure of the economy are surrounded by significant uncertainty, partly because we have not seen such an event before. The other reason is that Britain's status after Brexit is still uncertain, which makes it difficult for impact assessments to quantify the results of the outcome of the referendum. ${ }^{2}$ If no consensus is reached during the negotiations, the impact of Brexit may affect the economy and the financial intermediary system of the continent too, seriously hindering the growth of the remaining part of the European Union. As to the spillover effects expected in the global economic space, we use the experiences of the latest crisis as a point of reference.

The experiences related to the crisis of 2008-2009 made it clear that in the case of a significant economic shock, the situation of the financial system and the room for manoeuvre for the countercyclical fiscal policy may influence the expected growth path of economies in a stronger and more permanent way than the impacts coming through direct channels - from the current commercial and financial market relations (Szalai - Csortos 2015). Therefore, in the impact assessment of Brexit, secondary, i.e. indirect channels will also be considered in addition to the primary or direct channels (Balatoni - Virág 2016). Secondary channels include the lending activity and resilience to stress of the financial system as well as the room for manoeuvre for the economic policy, and these factors may amplify or offset the direct impacts coming from our external markets.

As opposed to the European situation, the vulnerability of Hungary has decreased considerably since the crisis of 2008-2009 (Matolcsy 2015). The economy went through a successful stabilisation period. The vulnerability of the country has been reduced, the fiscal balance has steadily improved, and the balance of payments shows a solid surplus. A growth of more balanced structure has started. The stability of the banking system has improved.

Now we describe the channels through which Brexit affects Hungarian macroeconomic processes, and considering the strength of individual impulses, we outline the impacts expected on Hungarian economy. For the full definition of the impacts, we distinguish between primary and secondary impacts (Figure 5). As a primary impact, foreign trade may slow down, the funds and money transfers coming from the EU may decrease on a longer term, and the possible deterioration of global willingness to take risks may trigger an increase in risk spread in emerging markets. Declining global commodity prices may cause an improvement in terms of trade. Also, on the medium term, working capital may start

2 Advocates of the exit did not outline their ideas about the new situation, and it is unlikely that the EU would accept the British position that has been formulated since the referendum, i.e. a free-trade area with restricted movement of labour. 


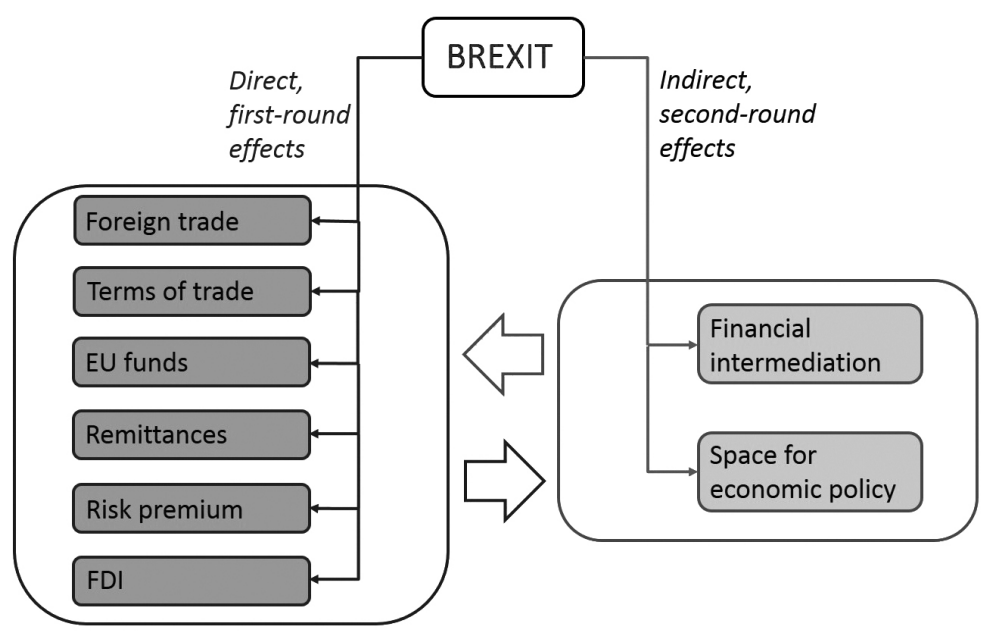

Figure 5. Channels determining the macroeconomic effects of Brexit on Hungary

to flow to the continent and to the Central and Eastern European region. In an extreme case, Brexit may result in feedbacks in EU and emerging countries that still have vulnerable financial systems. The vulnerability of the Hungarian financial system has been significantly reduced in the previous years, which limits the negative spillover effects. Another important point is that Brexit may trigger an economic policy reaction too, under which decision-makers may use active demand management tools to mitigate possible negative impacts. The extent of this reaction greatly depends on the size of the room for manoeuvre of individual countries and governments in the budget.

As for foreign trade, it is worth noting that Hungary's direct trade exposure to the British economy can be considered relatively low, as its share within the export of goods and services is less than 5\% (Table 2). This ratio is slightly lower than the ratio of Russia and Ukraine together before the deepening of the Russian-Ukrainian crisis. The experiences of that time indicate that as long as an external market problem remains local, exporters are able to flexibly adjust to the modified situation. However, if the spillover effects of the slowdown in Britain generally deteriorated the growth of the euro zone and mainly the outlooks of German exporting companies, it would have a negative impact also on the export outlook of the Central and Eastern European region. In this case, we have to consider indirect exposure too, as we have significant direct trade relations with the rest of the European Union (share of 75.2\%), and they may be affected by the transformation of trade relations with Britain. The impact of the general slowdown of our external demand on growth may be more significant, as exports 
Table 2. Shares related to the foreign demand, $\%$

\begin{tabular}{lr}
\hline Hungarian exports of goods and services (2014) & \\
\hline United Kingdom & 4.8 \\
EU (without UK) & 75.2 \\
\hline Exports (\% of GDP, 2015) & 92.1 \\
Import share of exports (SUT 2008) & 65.0 \\
\hline
\end{tabular}

Source: Hungarian Statistical Office, UNCTAD database.

Table 3. Britain's contribution to the 2007-2013 budget of the EU

\begin{tabular}{lr}
\hline EU budget (bn $€$ ) & 114.6 \\
\hline Britain's contribution (bn $€$ ) & 13.6 \\
Britain's expenditure (bn $€$ ) & 6.7 \\
\hline Britain's net contribution (bn $€$ ) & 6.9 \\
Proportion of EU budget $(\%)$ & 6.0 \\
\hline
\end{tabular}

Source: Eurostat.

represent a high ratio (92.1\%) within domestic GDP. However, this impact is mitigated by the high import contents of Hungarian exports $(65 \%)$.

The second channel, called terms of trade, is partly related to foreign trade, as, in parallel with the slower external demand, the demand of developed economies for raw materials goes down, and this may improve our terms of trade through the drop in prices. As a result of the improved terms of trade, our balance of payments will nominally improve, while on the other hand, our net exports will be adjusted also in volumes to the relative price change already on the short term, until the end of 2018, mitigating the unfavourable growth impact of the foreign trade channel.

With the exit of Britain, it is reasonable to ask how the lack of funds that are not contributed by the UK will affect the total funds of the EU as well as their structure, as the UK is a significant net contributor to the budget of the European Union (Table 3). This question is especially relevant in the case of the Central and Eastern European countries, as high amounts of structural and cohesion funds are forwarded to this region.

A number of analyses draw attention to the point that the inflow of EU funds to our region may drop already in the short term, deteriorating next year's growth too (Citibank 2016; Morgan Stanley 2016). However, according to our assessment, the change will not affect the present budgetary period of 2014-2020, or to a small extent only. Until the closing of the negotiations - regulated in Article 50 on withdrawal from the EU in the Lisbon Treaty - we expect the status quo to remain, i.e. Britain will probably continue paying its net $6 \%$ contribution to the EU budget until the end of 2018. Following that, the basic question is what kind 
of integration will be maintained. It is the common economic interest of the UK and the EU to maintain an economic co-operation that is as close as possible, and to avoid the re-establishment of customs duties. However, if we calculate with an extreme scenario - for instance, in the lack of an agreement - in which the funds to be paid by Britain will be fully missing from the EU budget from 2019, there are still multiple possible economic outcomes. On the one hand, the missing amount may be added by the remaining member states, and on the other hand, withdrawals may also be reduced in the ratio of payments. ${ }^{3}$ Obviously, direct real economic impacts need to be expected in the latter case only, when the missing funds would hinder both public and private investments. Even in an extreme case, the impact would not reach $0.2 \%$ of the GDP. ${ }^{4}$ It is important to emphasise, though, that in the generally low interest rate environment, the missing funds may be compensated better than ever by the affected member states, including Hungary, by promoting lending, and by utilising the existing fiscal room for manoeuvre. All in all, the impact of reduced EU funds on growth is practically zero in the short term, and it may be negligible in the medium term too, as a result of the existing room for manoeuvre available to the economic policy.

In the past few years, the amount of remittances sent home by Hungarian citizens working abroad has increased significantly. Some of the wage incomes they earn increases the demand in the Hungarian economy, as family members at home also receive an income from the transfers. According to the latest research (Meyer - Shera 2016), there is a significant and positive relation between remittances and economic growth. According to the balance of payment statistics, the total amount of remittances of people working in Great Britain is less than half a billion euros. Non-residents working in the UK actually transferred EUR 0.17 billion to Hungary in 2015, and the income of residents was EUR 0.2 billion (but this includes the costs of living there, too, and the actual transfer may be a fraction of that). The value of remittances in HUF - and their impact on domestic demand - is determined in the short term by the extent and the length of the weak-

3 In the latter case, we may suppose that the EU budget will not be curtailed with across-theboard cuts, and only the structural and cohesion funds will be reduced, while the expenditures on natural resources (e.g. agricultural aids) that make up nearly half of the EU budget, will be left intact. This would probably be defended by bigger nations too, therefore its value and base are more stable. Consequently, in the worst case, the funds we receive may drop by $12 \%$ per year after 2018.

4 Based on the 2014-2020 EU budget, the amount missing from EU funds may be slightly more than HUF 150 billion per year on average in 2019-2020, which is less than $0.4 \%$ of the GDP. Some of that is directed to the financing of private investments of high import contents (78\%), the other part is directed to public investments of lower import contents $(28 \%)$, as the Government is committed to spending $60 \%$ of the funds on economic development. Even in this extreme case, the impact of reduced EU funds on growth would not reach $0.2 \%$ of the GDP. 
ening of the pound, and in the medium term, by the new regulations regarding the movement of labour as defined in negotiations. Based on the views of experts, the EU may define the free movement of labour as a condition of maintaining closer economic relations (Dhingra - Sampson 2016; Portes 2016). In our view, this latter is in the interest of Great Britain too, so we do not expect stricter employment conditions or possible restrictions for employees working in the British economy. Even if a significant portion of the purchasing power of the amounts sent home is lost because of a possible very strong (10-20\%) depreciation of the British currency, the impact at the macroeconomic level would not even reach $0.1 \%$ of the GDP.

The fifth direct channel is the change in risk premium. Following the economic crisis in 2008, risk premium increased significantly in a number of countries, and received great attention among a wide range of investors. Hungary was no exception either, and the strong reliance on external funds - high FX debts both of the household sector and the Hungarian state - and the structural growth problems partly related to this resulted in the significantly worse risk perception of Hungary. The fiscal and monetary policy measures of recent years stabilised the external and internal balance, and significantly reduced vulnerability, and thus resulted in a fundamental change in the evaluation of the country. In 2013, Hungary was released from the excessive deficit procedure, and following the decision made by S\&P in September 2016, the country was upgraded to the investment grade by two credit rating agencies. After the British referendum, money market volatility increased in general, and the CDS spread of several countries grew significantly. This temporary effect, however, was quickly corrected in the case of Hungary: the CDS spread and the government bond yields dropped below the level before the referendum, and the forint appreciated against the euro. With its reduced vulnerability, the Hungarian economy enjoys the trust of investors, so we do not expect a substantial increase in risk premium because of Brexit. This is confirmed by the movements of indicators measuring vulnerability too. Among emerging economies, Hungary has showed the biggest improvement from 2008 to 2015 (Figure 6).

The last direct channel is the FDI channel. Multinational companies take several considerations into account in their investment decisions such as the qualifications of the workforce, the status of the infrastructure, the costs of production (wages, taxation environment), and macroeconomic uncertainty. Following the British referendum, many questions remained unanswered, but the uncertain environment is not favourable for the assessment of the UK by investors in the longer term. Recently, Japanese managers warned London that Japanese companies may transfer their head offices, and company groups of German interest in the car industry may make similar decisions. This may be supported by automo- 


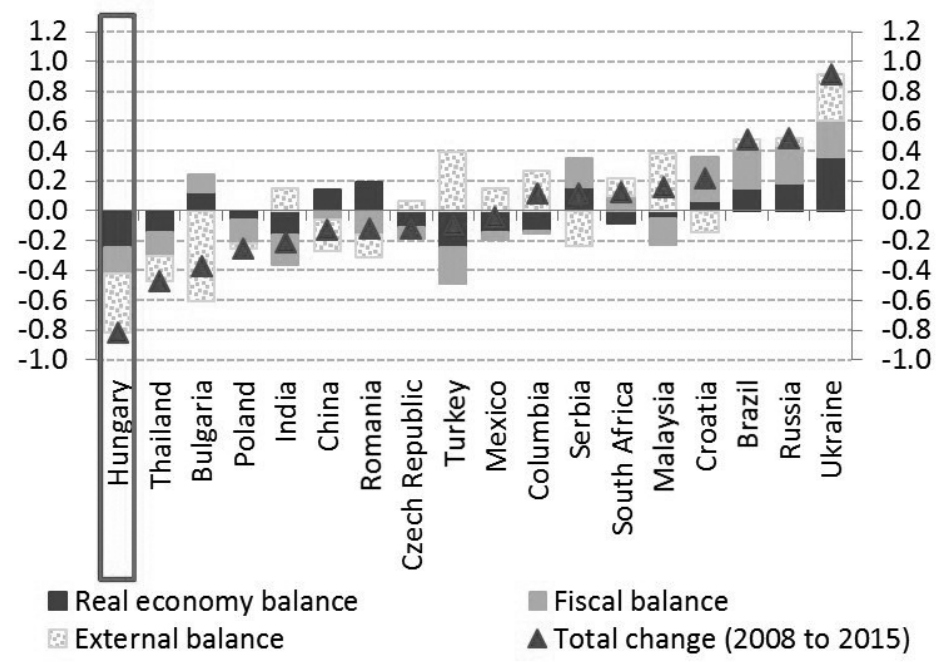

Figure 6. Change in MNB vulnerability index from 2008 to 2015

Note: Negative values mark improvement in vulnerability.

Source: Eurostat, MNB.

tive industry analyses, according to which withdrawal from the EU may cause an increase in trade and co-ordination costs, and thus a decline in production (Head - Mayer 2015; Dhingra et al. 2016). If this scenario is realised, the target of the transfer of manufacturing capacities may be the Central and Eastern European region. The region's countries may be selected primarily on the basis of low production costs, stable macroeconomic environment, and the positive experiences of the co-operation so far, and thus the capacities of the Hungarian economy may also increase.

Looking at indirect impacts, the improvement of the resilience of the Hungarian financial system has effectively reduced the possibility of the emergence of negative feedbacks. The Hungarian financial system has no direct linkages to that of Britain. However, the consequences of Brexit may sharpen the problems in the European banking system, which may have an effect on the Hungarian subsidiary banks through their European parents. Presently, the Hungarian banking system relies on foreign funds to a much less extent than before. On the one hand, the crisis forced financial institutions to make adjustments on the assets side (reduce lending). On the other hand, owing to the government and central bank measures made in the past years (final early repayment and conversion of FX loans to HUF), the risk presented by the high ratio of FX loans in the household portfolio practically ceased to exist. As opposed to the situation in 2008, 


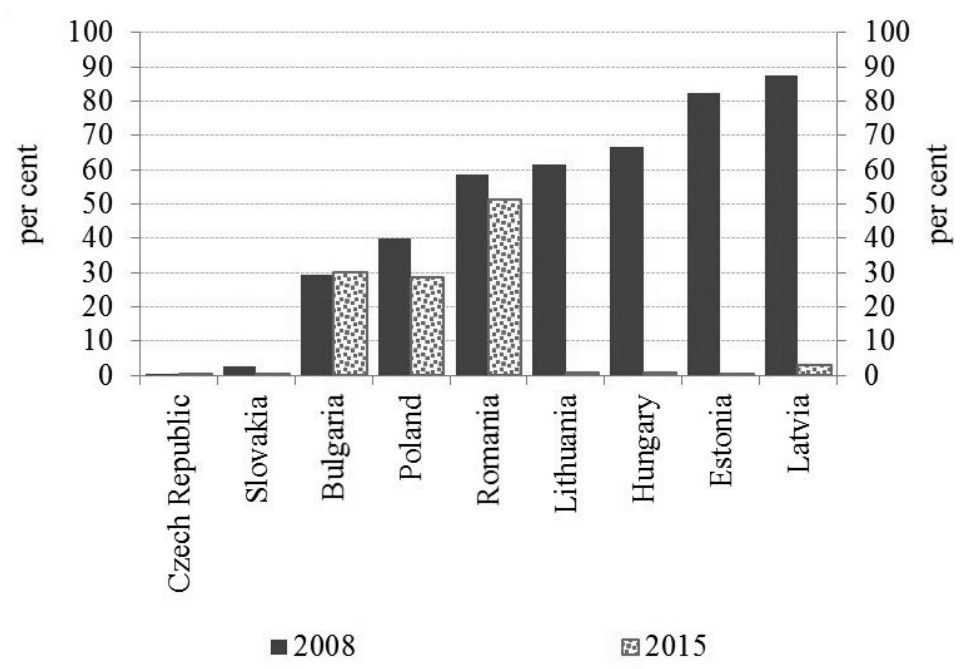

Figure 7. International comparison of change in the proportion of FX loans in the household portfolio

Source: Central banks' data.

Romania, Bulgaria, and Poland now have the highest ratio of a portfolio exposed to exchange rate fluctuations (Figure 7).

The liquidity and capital position of the Hungarian financial system is stable. Owing to the changes in regulatory requirements, capital requirement is higher than before the crisis. The profitability of the sector and the capital accumulation ability of banks improved in the past few years.

As the last channel, we review the tools of economic policy, which may mitigate macroeconomic impacts with countercyclical measures. Before the evaluation, it is important to point out that the Hungarian growth structure was increasingly shifted towards internal demand in the last few years. In the case of a slowdown on external markets, recessional impacts may be mitigated by a countercyclical economic policy, facilitating the utilisation of free capacities in the economy. The deficit of the Hungarian state budget is steadily low, it is expected to be $1.4-1.5 \%$ of the GDP this year, and around $2.1-2.3 \%$ next year. According to the forecast by the central bank, there is a substantial fiscal room for manoeuvre for the case of a possible slowdown on external markets, even without violating the debt and deficit rules of the EU.

All in all, we can say that the impact of Brexit on the Hungarian economy is likely to be moderate. Within the direct macroeconomic channels, the impact of the foreign trade channel may be the strongest if Brexit brings significant nega- 
tive impacts at the whole EU level. In this case, the negative impact on the growth of Hungarian exports is mitigated by the expected improvement in terms of trade. By our calculations, the drop in EU funds and remittances can have only a moderate impact on Hungarian growth. The vulnerability of Hungary has improved considerably since the crisis of 2008-2009. In line with that, the potential secondround impacts of Brexit will remain moderate, and they may be further mitigated by the economic policy by utilising the available room for manoeuvre.

\section{REFERENCES}

Atkinson, T. - Luttrell, D. - Rosenblum, H. (2013): How Bad Was It? The Costs and Consequences of the 2007-09 Financial Crisis. Dallas Fed Staff Papers, No. 20, July.

Baker, J. - Carreras, O. - Kirby, S. - Meaning, J. - Piggott, R. (2016): Modelling Events: The Shortterm Economic Impact of Leaving the EU. Economic Modelling, 58(November): 339-350.

Balatoni, A. - Virág, B. (2016): Brexit: nagyobb alkalmazkodási képesség, fél siker! (Brexit: greater adaptability, half the battle!) MNB. https://www.mnb.hu/letoltes/balatoni-andras-virag-barnabas-brexit-nagyobb-alkalmazkodasi-kepesseg-fel-siker.pdf

Baldwin, R. et al. (2015): Rebooting the Eurozone: Step 1 - Agreeing a Crisis Narrative. VOX, CEPR's Policy Portal, November.

Bell, B. - Machin, S. (2016): Brexit and Wage Inequality. In: Baldwin, R. (ed.): Brexit Beckons: Thinking Ahead by Leading Economists. Chapter 13, VoxEU.org Book, CEPR Press.

Christiano, L. - Eichenbaum, M. - Rebelo, S. (2011): When is the Government Spending Multiplier Large? Journal of Political Economy, 119(1): 78-121.

Citibank (2016): Hypotheticals: What Would Brexit Mean for the CEE? Central Europe Economics View.

Coyle, D. (2016): Brexit and Globalisation. In: Baldwin, R. (ed.): Brexit Beckons: Thinking Ahead by Leading Economists. Chapter 1, VoxEU.org Book, CEPR Press.

Csortos, O. - Szalai, Z. (2015): Difficulties in the Management of the Global Financial Crisis: Academic and Economic Policy Lessons. Financial and Economic Review, 14(3): 5-38.

Dhingra, S. - Ottaviano, G. - Sampson, T. - Van Reenen, J. (2016): The Impact of Brexit on Foreign Investment in the UK. CEP Brexit Paper.

Dhingra, S. - Sampson, T. (2016): UK-EU Relations after Brexit: What is Best for the UK Economy? In: Baldwin, R. (ed.): Brexit Beckons: Thinking Ahead by Leading Economists. Chapter 2, VoxEU.org Book, CEPR Press.

Eggertsson, G. B. (2010): The Paradox of Toil. Staff Report, No. 433, Federal Reserve Bank of New York.

Eggertsson, G. B. - Krugman, P. (2012): Debt, Deleveraging, and the Liquidity Trap: A FisherMinsky-Koo Approach. Quarterly Journal of Economics, 127(3): 1469-1513.

Eggertsson, G. B. - Mehrotra, N. R. (2014): A Model of Secular Stagnation. NBER Working Paper, No. 20574.

G20 (2010): The G-20 Toronto Summit Declaration. Canada, June 26-27.

Head, K. - Mayer, T. (2015): Brands in Motion: How Frictions Shape Multinational Production. CEPII Working Paper, No. 26.

Koo, R. C. (2008): The Holy Grail of Macroeconomics: Lessons from Japan's Great Recession. Singapore: John Wiley \& Sons. 
Koo, R. C. (2014): Balance Sheet Recession is the Reason for Secular Stagnation. In: Teulings, C. - Baldwin, R. (eds): Secular Stagnation: Facts, Causes and Cures. Chapter 11, VoxEU.org Book, CEPR Press.

Matolcsy, Gy. (2015): Economic Balance and Growth - Consolidation and Stabilisation in Hungary 2010-2014. Book Series of the Magyar Nemzeti Bank, Budapest: Kairosz Könyvkiadó.

Meyer, D. - Shera, A. (2016): The Impact of Remittances on Economic Growth: An Econometric Model. EconomiA (Journal of National Association of Postgraduate Centers in Economics, ANPEC, Brazil), http://dx.doi.org/10.1016/j.econ.2016.06.001

Milanovic, B. (2012): Global Income Inequality by the Numbers: In History and Now. Policy Research Working Paper, No. 6259, World Bank.

Nystedt, J. (2016): Market Pulse. Brexit: CEE Scenarios and Implications. Morgan Stanley Investemnt Management.

Ostry, J. D. - Loungani, P. - Furceri, D. (2016): Neoliberalism: Oversold? Finance \& Development, 53(2): 38-41.

Pain, N. - Young, G. (2004): The Macroeconomic Impact of UK Withdrawal from the EU. Economic Modelling, 21(3): 387-408.

Portes, J. (2016): Immigration - the Way Forward. In: Baldwin, R. (ed.): Brexit Beckons: Thinking Ahead by Leading Economists. Chapter 3, VoxEU.org Book, CEPR Press. 